\title{
Digitized Database of Old Seismograms Recorder in Romania
}

\author{
Daniel PAULESCU ${ }^{1,2}$, Maria ROGOZEA ${ }^{1}$, Mihaela POPA ${ }^{1}$, \\ and Mircea RADULIAN ${ }^{1,3}$
}

\author{
${ }^{1}$ National Institute for Earth Physics, Măgurele, România \\ e-mails: dpaulescu@infp.ro,mrogozea@infp.ro (corresponding author) \\ ${ }^{2}$ University of Bucharest, Faculty of Physics, Măgurele, România \\ e-mail: secretariat@fizica.unibuc.ro \\ ${ }^{3}$ Academy of Romanian Scientists, Bucharest, Romania
}

\begin{abstract}
The aim of this paper is to describe a managing system for a unique Romanian database of historical seismograms and complementary documentation (metadata) and its dissemination and analysis procedure. For this study, 5188 historical seismograms recorded between 1903 and 1957 by the Romanian seismological observatories (Bucharest-Filaret, Focşani, Bacău, Vrincioaia, Câmpulung-Muscel, Iaşi) were used. In order to reconsider the historical instrumental data, the analog seismograms are converted to digital images and digital waveforms (digitization/vectorialisation). First, we applied a careful scanning procedure of the seismograms and related material (seismic bulletins, station books, etc.). In a next step, the high resolution scanned seismograms will be processed to obtain the digital/numeric waveforms. We used a Colortrac Smartlf Cx40 scanner which provides images in TIFF or JPG format. For digitization the algorithm Teseo2 developed by the National Institute of Geophysics and Volcanology in Rome (Italy), within the framework of the SISMOS Project, will be used.
\end{abstract}

Key words: historical seismograms, database, digitization, Romania.

Ownership: Institute of Geophysics, Polish Academy of Sciences;

(C) 2016 Paulescu et al. This is an open access article distributed under the Creative Commons Attribution-NonCommercial-NoDerivs license,

http://creativecommons.org/licenses/by-nc-nd/3.0/. 


\section{INTRODUCTION}

Consideration of earthquakes from historical perspective is of major interest for seismic hazard and risk assessment, and particularly for strategic buildings and infrastructures, such as nuclear power plants, since in these cases the knowledge about seismicity over long time intervals is required. Instrumental data available for the historical period have, contextually, a crucial scientific significance and allow the earthquake instrumental catalogues to be extended over 100 years period.

Instrumental seismology actually started at the end of the 19th century and the beginning of the 20th century (Dewey and Byerly 1969). Most observatories in the World and in Romania as well, still keep the original recordings (seismograms, bulletins).

The large interest of the international seismological community comes from the 1980s, after IASPEI resolution was set up, followed up by the creation of the World Data Centre A (WDC-A) and the IASPEI/UNESCO Working Group on Historical Seismograms. A systematic activity has started since then to archive seismograms using the microfilming technique (Glover and Meyers 1988).

Digital archiving techniques have been developed recently in order to preserve the unique seismological patrimony consisting in historical seismograms, earthquake bulletins and related documentation (e.g., observatory log books, station books, correspondence, etc.). The seismological community has become increasingly aware of the utmost importance to avoid deterioration and loss over time and to save the scientific and informational content of this unique seismological heritage consisting of historical seismograms. At the same time, the digital format allowed the re-analysis of the past earthquakes using modern techniques and re-evaluation of seismic hazard (Kanamori 1988, Michelini et al. 2005).

In 2001, Instituto Nazionale di Geofisica e Vulcanologia (INGV) from Italy started an innovative project ("Progetto SISMOS"; i.e., SISMOgrammi Storici) focused on scanning at very high-resolution, and archiving seismological paper records and related material (metadata). In 2002, the SISMOS activity was extended to seismograms and bulletins from 28 countries of the Euro-Mediterranean area, including Romania, through the EuroSeismos Project (Saving and Studying the Seismograms of the Strongest EuroMediterranean Earthquakes; http://storing.ingv.it/es_web) conducted by Working Group on the History of Seismometry of European Seismological Commission. In parallel, W.H.K. Lee initiated the project "SeismoArchive" under the auspices of the International Committee for Preservation of WWSSN (World Wide Seismographic Stations Network) and Historical Seismograms (ICPWHS) of the International Association of Seismology and 
Physics of the Earth's (IASPEI), in collaboration with Data Management Center (DMC) of the Incorporated Research Institution for Seismology (IRIS) (IRIS 2004).

SISMOS was one of the Transnational Access facilities of the European Commission (EC FP7) NERIES (Network of Research Infrastructures for European Seismology) Project (2006-2010). SISMOS is partner in the GEM Project (2009-2013) for the construction of a Global Instrumental Seismic Catalogue (http://www.globalquakemodel.org/science).

The goal of this paper is to present the database of historical instrumental data (seismograms, seismic bulletins and complementary documentation) developed in digital format for recordings in Romania. Such a database is of highest interest from many points of view: (i) the conservation of the entire information of seismic activity; (ii) the huge volume of data can be used in many scientific fields (seismic risk and hazard, seismic source and seismotectonic studies, etc.); (iii) it provides an objective basis for many applications (relocation, retrieval of source parameters, synthetic seismograms); (iv) fast and efficient exchange of data between observatories; (v) structuring and integrating of existing information about historical earthquakes. A brief history of seismology in Romania is presented in Section 2. The methodology to set up the database is described in Section 3.

\section{BRIEF HISTORY OF SEISMOLOGY IN ROMANIA}

The Romanian tradition in geophysical research began with the astronomer and meteorologist Stefan Hepites (1851-1922). Through his contributions to the study and monitoring of earthquakes, he is considered the father of Observational Seismology in Romania. Hepites organized a continuous monitoring of seismic activity in the framework of the National Institute of Meteorology, starting with 400 observation "stations" (locations with volunteer observes).

Specific instructions were set up for the use of volunteers in order to note earthquakes. The first list of old earthquakes recorded in Romania was compiled and was published in the Register of Earthquakes in 1893. The Register was then published yearly. The model of this seismological survey and collection of information about the earthquakes was adopted for organizing similar networks in other earthquake prone countries, such as Bulgaria and Chile.

Hepites compiled in 1893 the first Romanian catalog of earthquakes, including earthquakes recorded between 1838 and 1892. The catalog was published in Romanian and French in the same year (Hepites 1893).

Hepites founded also, in 1895, the first seismic station in Romania, located in Bucharest, on the Filaret hill. The first instrument for seismic records that worked in Bucharest was a micro-seismoscop Tacchini-Guzzi and a 
pendulum. In 1896, he built a new pavilion for terrestrial magnetism measurements and organized an accurate time service.

In 1901 the Romanian Seismological Service was established. Two horizontal Bosch seismographs of $10 \mathrm{~kg}$ mass, mechanical amplification of 10 to 15 times and recording on a reel covered with smoked paper (Fig. 1) were installed in 1902. An electric clock marked the minutes on the paper (Radulescu 2009). These pendulums became part of the history of seismology, their records being used by Jeffreys (1935) to demonstrate the existence of deep earthquakes.

In 1935, two pendulums were installed additionally in Bucharest by Demetrescu (1956) from the Astronomical Institute of Bucharest. They had masses of $540 \mathrm{~kg}$ and static amplification of 170-180 with air damping. Demetrescu also organized a network of seismic stations to record earthquakes in Romania: two stations at Focsani and Bacau (1942), and three stations at Câmpulung-Muscel (1943), Iaşi (1951), and Vrincioaia (1952).

A seismological observatory was installed at Timisoara (TIM) in 1902 in the western part of Romania (Banat region), under the Austro-Hungarian administration. This seismic station has been working continuously until 1914 (Demetrescu 1956). Ioan Curea, professor at the University of Timisoara, revived the seismic monitoring in Banat by reinstalling at Timisoara in 1943 two horizontal mechanical pendulums of $540 \mathrm{~kg}$. Except of an interrup-

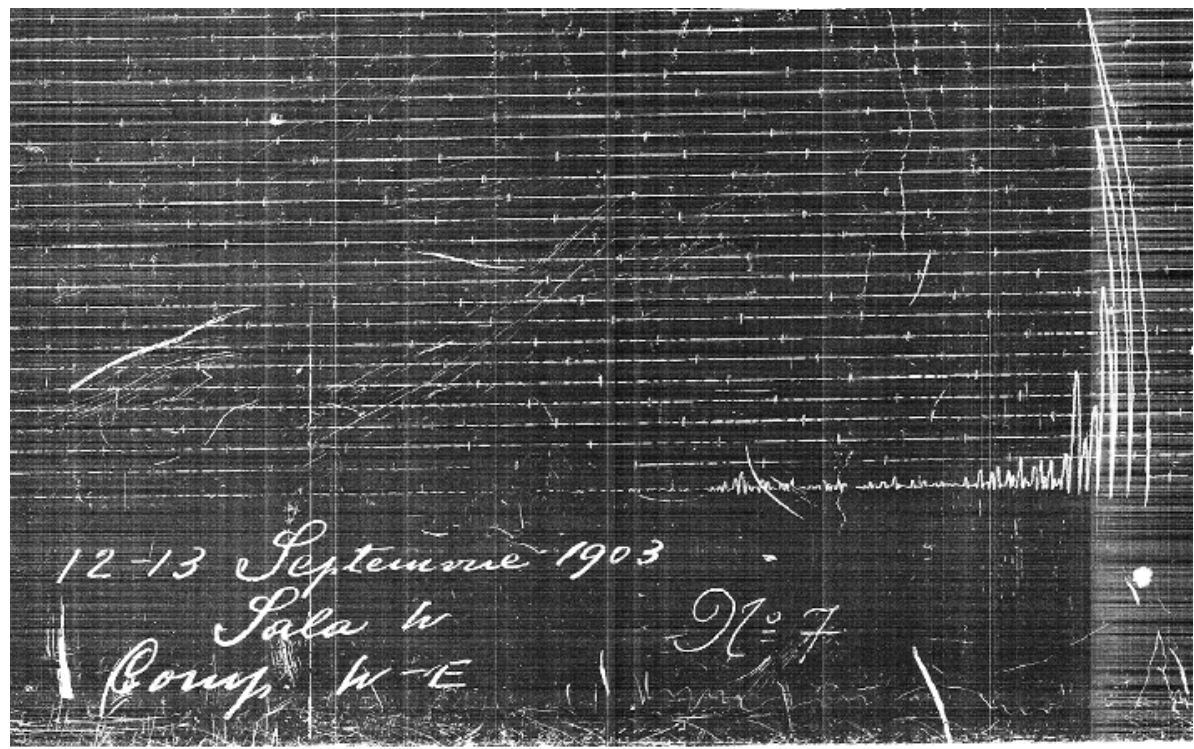

Fig. 1. Bosch mechanical pendulum seismogram recorded by EW component for the Vrancea earthquake of 13 September 1903, at 10:02 GMT $(M=6.3)$. Half of the motion trace is available. 
tion interval from 1944 to 1950 , this station has been operating continuously until the present days (Curea 1961). Curea also founded a seismic station at Cluj (1939), belonging to the Astronomical Observatory of the University of Cluj.

\section{THE DATABASE OF THE STUDIED SEISMOGRAMS}

\subsection{Data}

The archive of seismograms of the Bucharest Seismological Observatory was used for this study. We scanned up to now 5188 seismograms recorded at the following seismic stations: Bucharest-BUC (1903), Focşani-FOC (1942), Bacau-BAC (1942), Câmpulung-Muscel-CMP (1943), Iasi-IAS (1951) and Vrincioaia-VRI (1952) - see Fig. 2.

These seismograms were recorded on smoked paper (Mainka-Demetrescu instruments having a speed paper of $30 \mathrm{~mm} / \mathrm{min}$ ) and photo paper (Galitin and Alfany instruments). The characteristics of these seismographs are presented in Table 1. The seismograms contain or not the worldwide earthquakes recorded between 1903 and 1957.

The database of these seismograms includes also information related to seismic bulletins, publications, historical reference to earthquakes and seismic equipment.

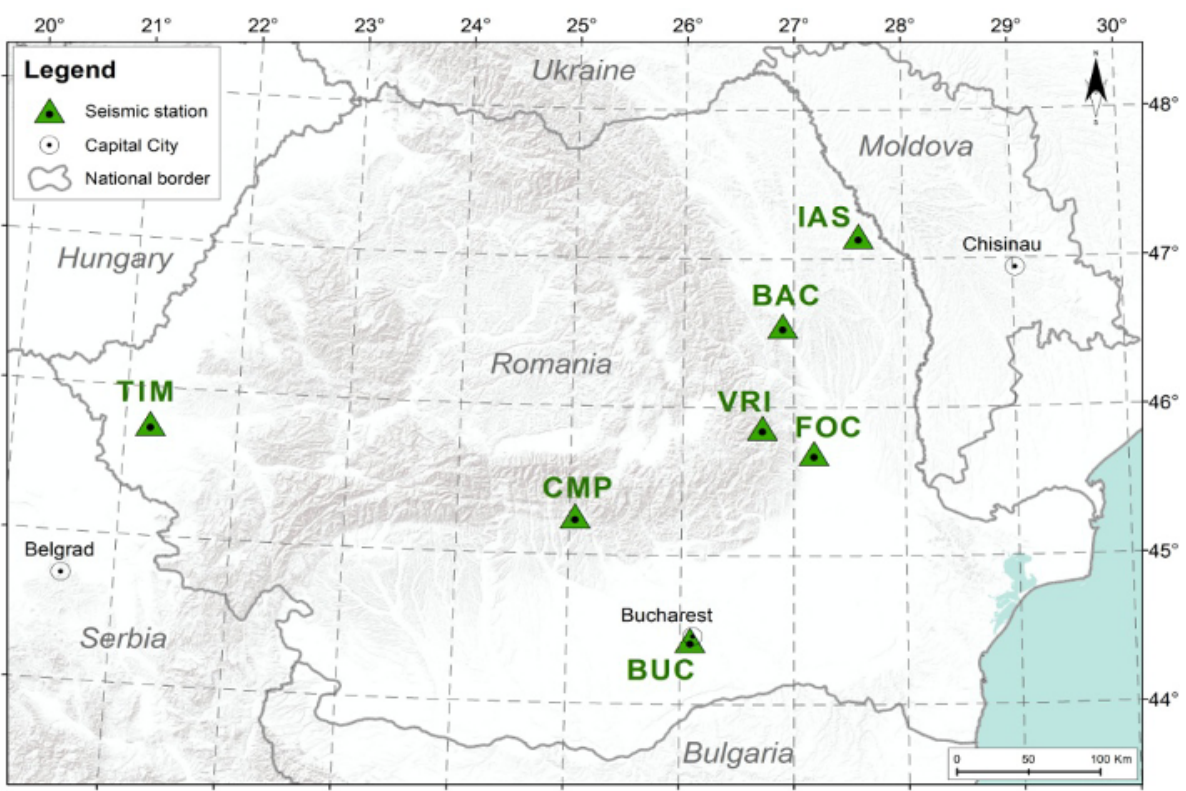

Fig. 2. Seismic stations distribution. 
Table 1

List of stations and seismographs

with the associated constants and year of installation

\begin{tabular}{|c|c|c|c|c|c|c|c|c|c|}
\hline \multirow[b]{2}{*}{$\begin{array}{l}\text { Station } \\
\text { code }\end{array}$} & \multirow[b]{2}{*}{ Station } & \multicolumn{2}{|c|}{ Coordinates } & \multirow{2}{*}{$\begin{array}{c}\text { Instruments } \\
\text { (seismograph } \\
\text { type) }\end{array}$} & \multirow[b]{2}{*}{ Comp } & \multirow[b]{2}{*}{$\begin{array}{c}M \\
{[\mathrm{~kg}]}\end{array}$} & \multirow[b]{2}{*}{$\begin{array}{l}T_{0} \\
{[\mathrm{~s}]}\end{array}$} & \multirow[b]{2}{*}{$V$} & \multirow[b]{2}{*}{$\mu^{2}$} \\
\hline & & $\begin{array}{l}\text { Lati- } \\
\text { tude } \\
\left({ }^{\circ} \mathrm{N}\right) \\
\end{array}$ & $\begin{array}{c}\text { Longi- } \\
\text { tude } \\
\left({ }^{\circ} \mathrm{E}\right)\end{array}$ & & & & & & \\
\hline \multirow{4}{*}{ BUC } & \multirow{4}{*}{$\begin{array}{c}\text { Bucharest } \\
\text { Cutitul } \\
\text { de Argint }\end{array}$} & \multirow{4}{*}{44.41} & \multirow{4}{*}{26.09} & $\begin{array}{c}\text { Bosch } \\
1903\end{array}$ & $\begin{array}{l}\text { NS } \\
\text { EW }\end{array}$ & $\begin{array}{l}10 \\
10\end{array}$ & $\begin{array}{l}? \\
?\end{array}$ & $\begin{array}{l}10 \\
15\end{array}$ & $\begin{array}{l}? \\
?\end{array}$ \\
\hline & & & & \begin{tabular}{|c|} 
Mainka- \\
Demetrescu \\
1935 \\
\end{tabular} & $\begin{array}{l}\text { NS } \\
\text { EW }\end{array}$ & $\begin{array}{l}540 \\
540\end{array}$ & $\begin{array}{l}12.2 \\
12.2\end{array}$ & $\begin{array}{l}165 \\
171\end{array}$ & $\begin{array}{l}0.81 \\
0.79\end{array}$ \\
\hline & & & & $\begin{array}{c}\text { Galitin } \\
1937\end{array}$ & $\begin{array}{l}\mathrm{NS} \\
\mathrm{EW}\end{array}$ & $\begin{array}{l}2.7 \\
2.7 \\
\end{array}$ & $\begin{array}{l}11.5 \\
11.5 \\
\end{array}$ & $\begin{array}{l}273 \\
270 \\
\end{array}$ & $\begin{array}{l}0.04 \\
0.02 \\
\end{array}$ \\
\hline & & & & $\begin{array}{c}\text { Alfani } \\
1940\end{array}$ & Z & 7.2 & 4.0 & 400 & $?$ \\
\hline FOC & Focsani & 45.70 & 27.18 & $\begin{array}{c}\text { Mainka- } \\
\text { Demetrescu } \\
1942 \\
\end{array}$ & $\begin{array}{l}\text { NS } \\
\text { EW }\end{array}$ & $\begin{array}{l}105 \\
105\end{array}$ & $\begin{array}{l}3.6 \\
3.6\end{array}$ & $\begin{array}{l}41 \\
37\end{array}$ & $\begin{array}{l}0.84 \\
0.77\end{array}$ \\
\hline $\mathrm{BAC}$ & Bacau & 46.57 & 26.91 & $\begin{array}{c}\text { Mainka- } \\
\text { Demetrescu } \\
1942 \\
\end{array}$ & $\begin{array}{l}\text { NS } \\
\text { EW }\end{array}$ & $\begin{array}{l}105 \\
105\end{array}$ & $\begin{array}{l}3.4 \\
3.6\end{array}$ & $\begin{array}{l}45 \\
42\end{array}$ & $\begin{array}{l}0.82 \\
0.82\end{array}$ \\
\hline CMP & $\begin{array}{c}\text { Campulung } \\
\text {-Muscel }\end{array}$ & 45.27 & 25.04 & \begin{tabular}{|c|} 
Mainka- \\
Demetrescu \\
1943 \\
\end{tabular} & $\begin{array}{l}\text { NS } \\
\text { EW }\end{array}$ & $\begin{array}{l}105 \\
105\end{array}$ & $\begin{array}{l}3.5 \\
3.5\end{array}$ & $\begin{array}{l}41 \\
41\end{array}$ & $\begin{array}{l}0.82 \\
0.81\end{array}$ \\
\hline IAS & Iasi & 47.19 & 27.56 & \begin{tabular}{|c|} 
Mainka- \\
Demetrescu \\
1951 \\
\end{tabular} & $\begin{array}{l}\mathrm{NS} \\
\mathrm{EW}\end{array}$ & $\begin{array}{l}450 \\
450\end{array}$ & $\begin{array}{l}4.8 \\
4.8\end{array}$ & $\begin{array}{l}127 \\
132\end{array}$ & $\begin{array}{l}0.85 \\
0.85\end{array}$ \\
\hline VRI & Vrincioia & 45.87 & 26.73 & \begin{tabular}{|c|} 
Mainka- \\
Demetrescu \\
1952
\end{tabular} & $\begin{array}{l}\text { NS } \\
\text { EW }\end{array}$ & $\begin{array}{l}105 \\
105\end{array}$ & $\begin{array}{l}3.5 \\
3.5\end{array}$ & $\begin{array}{l}41 \\
39\end{array}$ & $\begin{array}{l}0.71 \\
0.80\end{array}$ \\
\hline
\end{tabular}

Explanations: Instruments - there are two basic types of seismographs: one type uses a mass suspended by a pendulum; the other is based on a device which responds to strain; Comp - components of a seismograph: Z (vertical), EW (EastWest), and NS (North-South). A single seismograph records only one of these three components of motion; $M$ - mass pendulum: mass attached to a fixed base; $T_{0}-$ natural period of pendulum; $\mu^{2}$ - damping coefficient; $V$ - magnification.

\subsection{Methodology}

The modern techniques used for imaging and seismic signal processing allows recovering of important information from historical analogue recordings, essential to characterize seismic activity and related seismic hazard 
in earthquake prone regions. The major benefit is the possibility of converting analogue to digital data and, thus, analyzing them using modern techniques and methods, specific to the Digital Seismology.

The flow-chart displayed in Fig. 3 explains the procedure followed to set up the database. It is similar with that developed within the framework of the EuroSeismos Project 2002-2007 and has two main stages:

\section{Stage 1. Scanning and image processing}

The initial scanning is done for all available seismograms at 400 dpi resolution even if they do not contain visible events. They are saved in JPEG format as a useful collection for a preview of the database content. This component is the core of the database.

\section{Scanning and image processing}

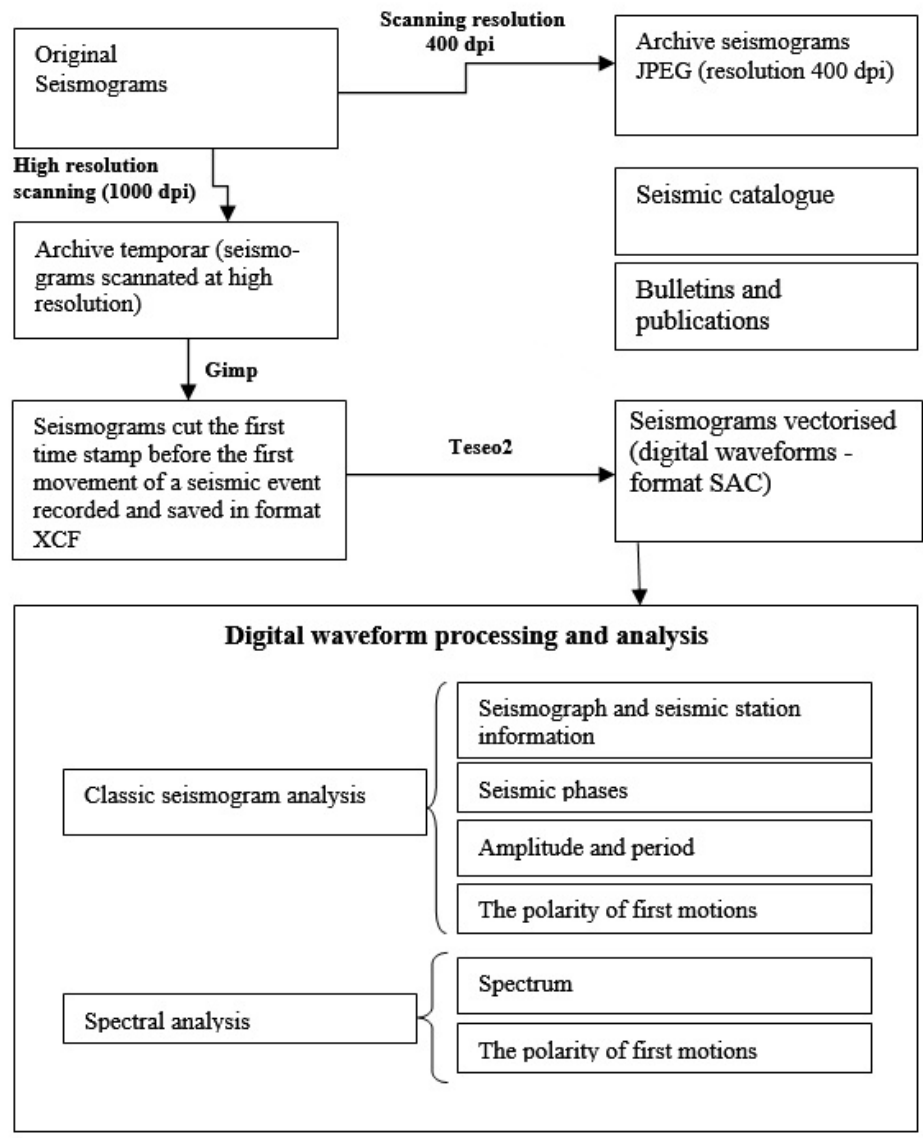

Fig. 3. Flow chart of the procedure proposed in the present work. 


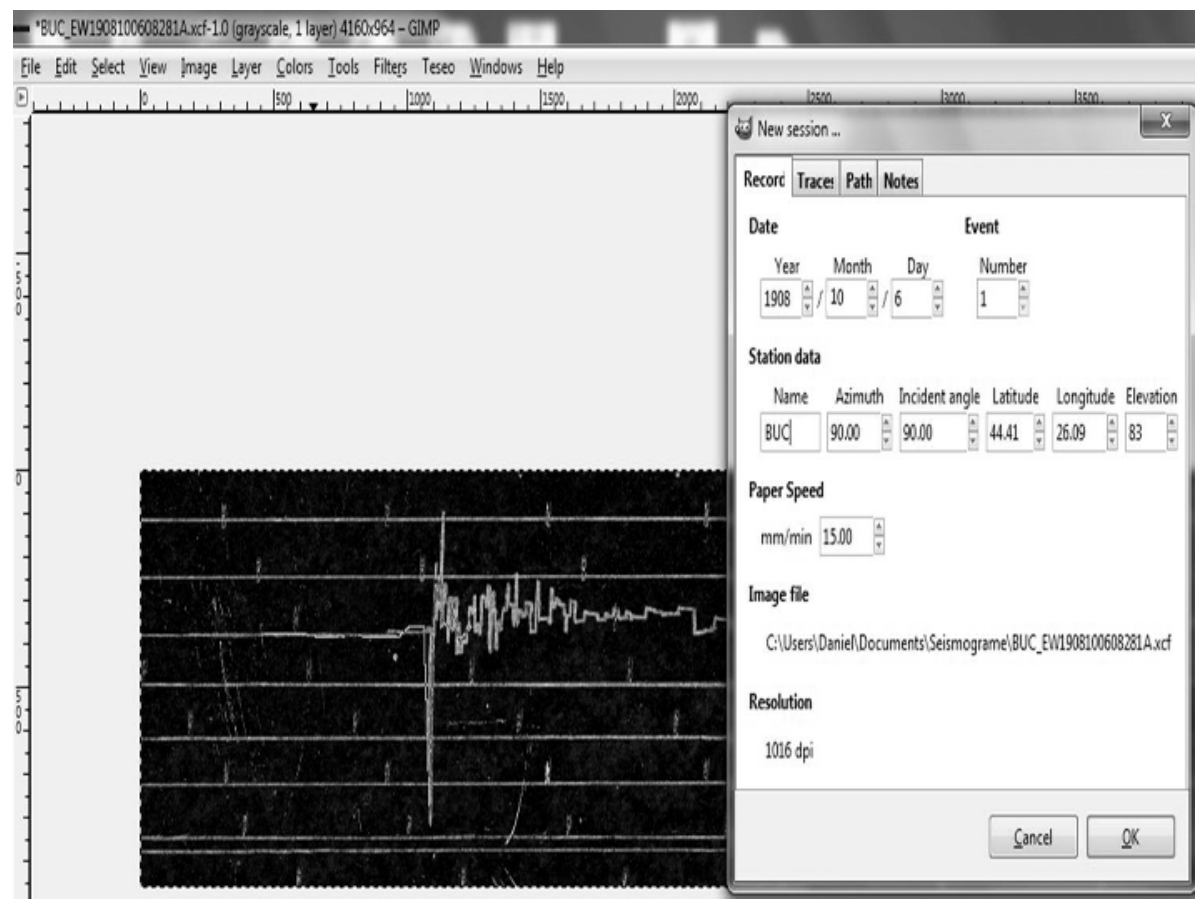

Fig. 4. Example of an extracted seismogram recorded by Bosch seismograph (EW component) for a Vrancea earthquake (6 October 1908 , latitude $45.50^{\circ} \mathrm{N}$, longitude $26.50^{\circ} \mathrm{E}, M=6.8$ ), prepared to be digitized and vectorized.

The seismograms of an earthquake that show good quality (high contrast) are also scanned at 1000 dpi resolution and saved in a TIFF format. Because the memory required for such a seismogram is very large, only the image that contains the waveform traces of the earthquakes of interest is scanned. Using GIMP software the trace of a given seismic event is (i) processed (e.g., improving the contrast of the seismic traces) and (ii) extracted from the seismogram by marking the window including only the useful recording. The dig out seismogram is saved in XCF format, specific for GIMP (Fig. 4). The outcome files in XCF format can now be digitized and vectorized using Teseo software developed by Pintore et al. (2005).

After digitization, the file with the seismogram data points is exported in SAC format in order to be processed (Fig. 5) during the next stage.

\section{Stage 2. Digital waveform processing and analysis}

At this stage any standard tool for digital processing of the signals can be applied (Fig. 6). Frequently, good results can be obtained for reassessing the location and magnitude of the earthquakes, estimation the focal mechanism 


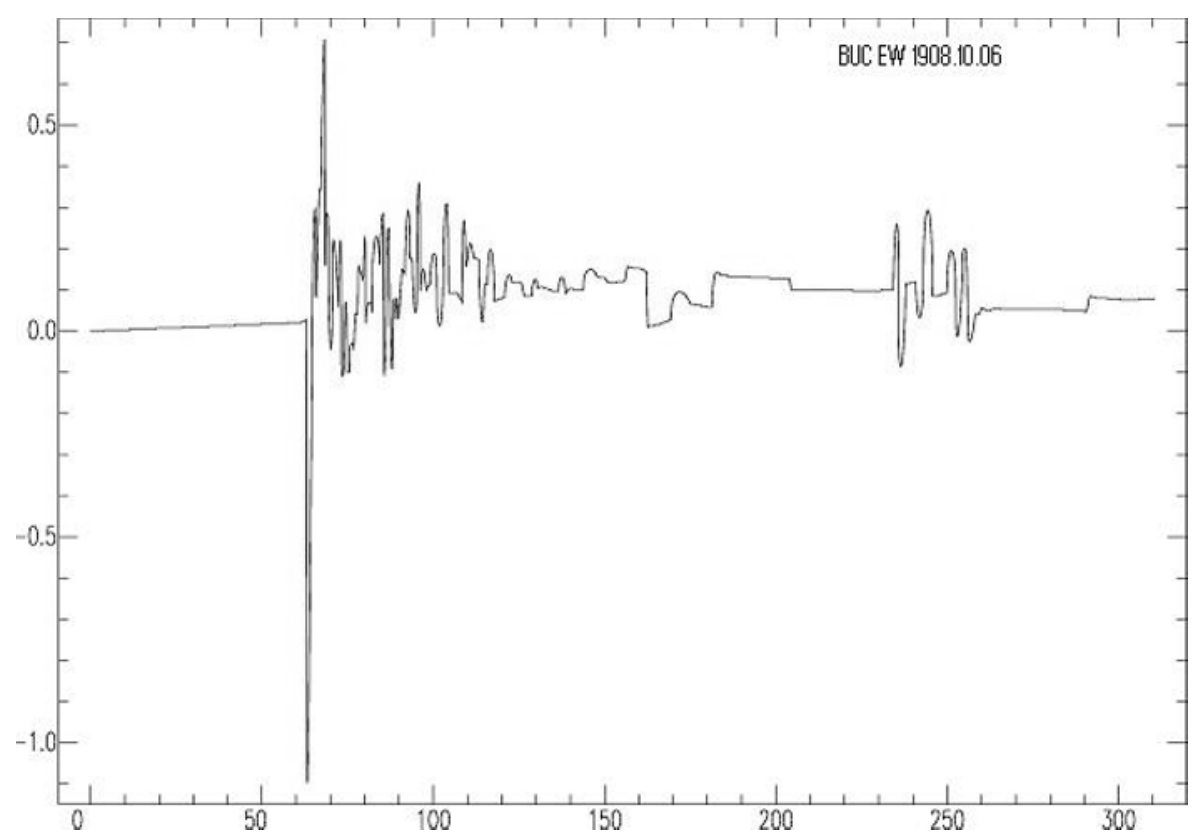

Fig. 5. Example of a seismogram ready to be exported in SAC format (the same event as in Fig. 4).

solutions and their spectral parameters (seismic moment, Mo, moment magnitude, $M w$, corner frequency and seismic fault dimensions). For correcting the seismogram trace curvature, the TESEO2 algorithm is applied (Pinatore et al. 2005).

\section{DATABASE}

The new created database has the structure described in Table 2 . The number in the second column represents the name designed to the scanned seismogram. The information in Box is a code of the file containing a group of seismograms stored in a separate place. It is useful to search easily the physical seismogram of an event. The other columns refer to the number of seismogram, station which recorded the event, components (EW, NS, Z), date, time of starting and ending of the record, type of instrument and quality factor $Q$, which indicates how well the earthquake was recorded on seismogram (A-very good, B-good, C-low, D-noise). The database includes scanned seismograms even if no earthquake was recorded (empty space in the box of the quality factor means that there is no recorded earthquake on seismogram for that time interval).

The archive of seismograms scanned at 400 dpi resolution is accessible on the website (www.archive.infp.ro). The database contains recordings 
Table 2

Database of scanned seismograms

\begin{tabular}{|c|c|c|c|c|c|c|c|c|c|c|c|}
\hline \multirow{2}{*}{$\begin{array}{l}\text { Box } \\
\text { A1 }\end{array}$} & \multirow{2}{*}{\begin{tabular}{|c|} 
No. \\
1
\end{tabular}} & \multirow{2}{*}{$\begin{array}{l}\text { Station } \\
\text { BUC }\end{array}$} & \multicolumn{3}{|c|}{ Component } & \multirow{2}{*}{\begin{tabular}{|c|}
$\begin{array}{c}\text { Start date of } \\
\text { the record }\end{array}$ \\
25 May 1903 \\
\end{tabular}} & \multirow{2}{*}{\begin{tabular}{|c|}
$\begin{array}{c}\text { Start } \\
\text { time }\end{array}$ \\
$10: 55$ \\
\end{tabular}} & \multirow{2}{*}{ 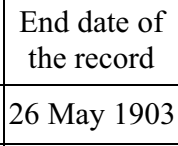 } & \multirow{2}{*}{\begin{tabular}{|c|}
$\begin{array}{c}\text { End } \\
\text { time }\end{array}$ \\
$10: 10$ \\
\end{tabular}} & \multirow{2}{*}{\begin{tabular}{|c|} 
Instrument \\
BS_2 \\
\end{tabular}} & \multirow{2}{*}{ Q } \\
\hline & & & NS & & & & & & & & \\
\hline $\mathrm{A} 1$ & 2 & BUC & & EW & & 25 May 1903 & $10: 55$ & 26 May 1903 & 10:08 & BS_1 & \\
\hline A1 & 3 & BUC & & EW & & 29 May 1903 & $9: 46$ & 30 May 1903 & $10: 52$ & BS_1 & \\
\hline A1 & 4 & BUC & NS & & & 29 May 1903 & $9: 47$ & 30 May 1903 & $10: 45$ & BS_2 & \\
\hline A1 & 5 & BUC & & EW & & 8 Jun 1903 & $11: 08$ & 9 Jun 1903 & $8: 02$ & BS_1 & \\
\hline A1 & 6 & BUC & & EW & & 903 & $10: 19$ & 1903 & $10: 15$ & BS & A \\
\hline A1 & 7 & BUC & NS & & & 12 Sep 1903 & $10: 16$ & 13 Sep 1903 & $10: 20$ & BS_2 & B \\
\hline A1 & 8 & BUC & & EW & & 27 Nov 1903 & $10: 34$ & 28 Nov 1903 & $10: 53$ & BS_1 & B \\
\hline A1 & 9 & BUC & & EW & & 29 Nov 1903 & $10: 18$ & 30 Nov 1903 & $10: 48$ & BS_1 & B \\
\hline A1 & 10 & BUC & & EW & & 5 Dec 1903 & $10: 20$ & 6 Dec 1903 & $10: 35$ & BS_1 & B \\
\hline A1 & 11 & BUC & & EW & & 5 Feb 1904 & $10: 41$ & 6 Feb 1904 & $5: 27$ & BS_1 & B \\
\hline A1 & 12 & BUC & NS & & & 5 Feb 1904 & $10: 40$ & 6 Feb 1904 & $5: 33$ & BS_2 & \\
\hline A1 & 13 & BUC & $\mathrm{NS}$ & & & 4 Apr 1904 & $10: 32$ & 4 Apr 1904 & & BS_2 & B \\
\hline$\cdots$ & $\cdots$ & $\cdots$ & $\cdots$ & $\cdots$ & & $\cdots$ & $\cdots$ & $\cdots$ & $\cdots$ & $\cdots$ & $\cdots$ \\
\hline A4 & 750 & BUC & NS & EW & & 4 Jan 1940 & $17: 50$ & 5 Jan 1940 & $05: 33$ & Galitin & A \\
\hline $\mathrm{A} 4$ & 832 & BUC & & & $\mathrm{Z}$ & 28 Dec 1940 & $17: 30$ & 29 Dec 1940 & $05: 30$ & Alfani & \\
\hline
\end{tabular}

Explanations: Box - code of the file containing a group of seismograms stored in a separate place; No. - number of scanned seismogram; Station - station code; Component - components of the instruments; Start/End of the record - date of beginning of the seismograms; Start/End time - time (hour and minutes) of the beginning/end of the seismogram; Instrument - type of instrument (BS - Bosh), Q the quality of recorded event (A-very good, B-good, C-low, D-noise).

from local, regional and distant earthquakes occurred since 1903 and will provide information of interest at national, regional/European and global scale. As an example, the seismogram recorded at Bucharest station (Bosch instrument) for an earthquake $(M w=7.3)$ occurred in Iran in 1909 is represented in Fig. 6. As a direct consequence, it will contribute to intensification of data exchange with other seismological centers.

The database includes also seismic bulletins, publications, historical references to the earthquakes and the characteristics of the seismic instruments, 


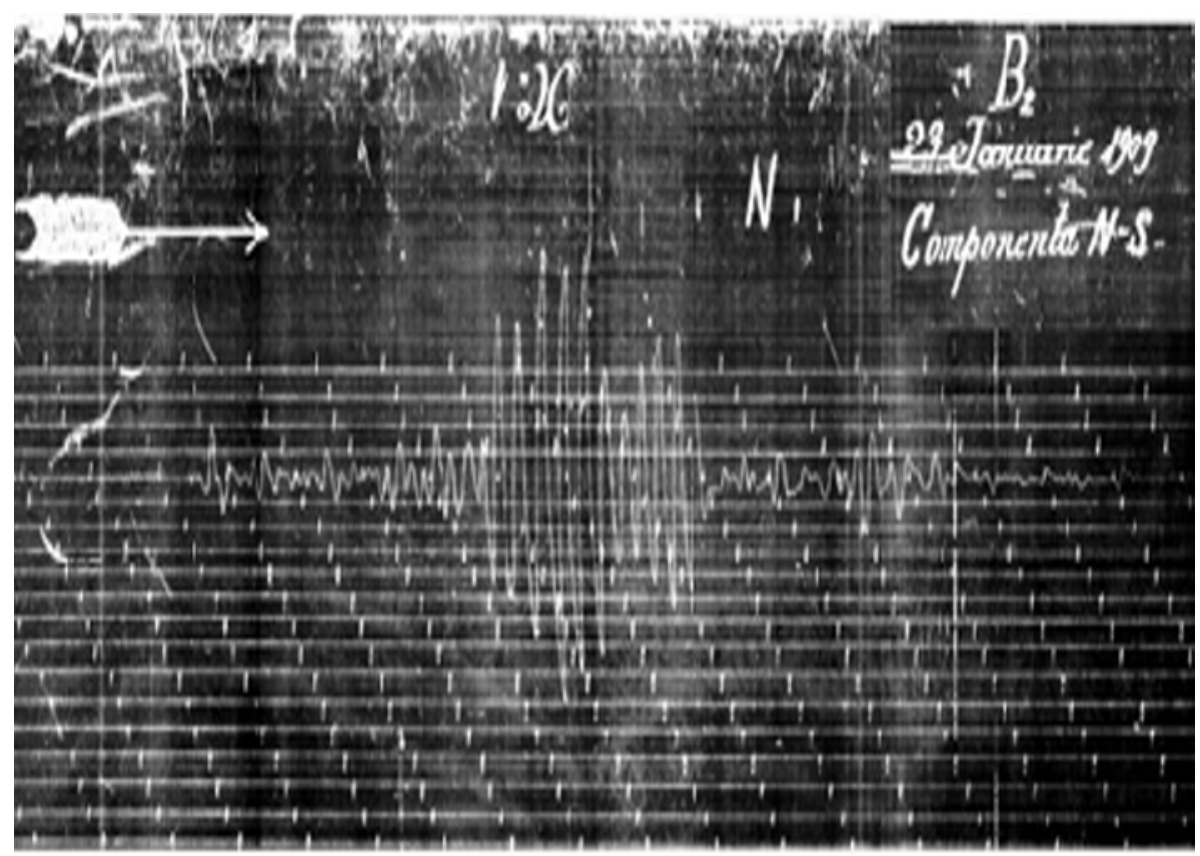

Fig. 6. Event from 23 January 1909, Silakhor, Iran (Persia); latitude $33.4^{\circ} \mathrm{N}$, longitude $49.1^{\circ} \mathrm{E}, M w=7.3$.

useful for knowing the instrument response function and the time corrections of the seismic phases input (Figs. 7 and 8).

At the same time, all the information provided by other seismological observatories related to strong earthquakes occurred in Romania will be included in the database. The database will be extended with the macroseismic information (notes, reports, documents, papers, maps, photos, etc.) whenever they are available.

A lot of such information is now available from the European historical earthquake catalogue (Stucchi et al. 2013) and from the integrated macroseismic database for the Vrancea strong events (Kronrod et al. 2013).

\section{CONCLUSIONS}

Romania is a country with long history in earthquake activity investigation using instrumental records. Therefore, any tool able to take advantage of the potential information from past recordings is of extreme interest.

We developed a unique instrumental database that archives historical seismograms recorded between 1903 and 1957 by Romanian seismic stations (5188 earthquakes) and as well as all the available complementary documen- 
No. 7. St. C. Hepites. ARHIVA sısMicX A rovikizi. ANI $1902-1906$.

\section{Enregistrements sismiques - 1908 - Inregistrări sismice.}

r $=$ Début des tremors. - Inceputul tremurăturilor.
$3=$ Début des oscillations. - Ineeputul oscilatiunilor.

$\mathbf{R}=$ Les oscillations deviennent plus fortes. - Oscilatiunile se

$\mathrm{F}=$ Fin des oseillations. - Finele oscilatiunilor.
$\mathrm{A}=$ Amplitudine complète de la plus grande oseillation. - Am

plitudine complectă a celei mai mari oscillaţíñi.

$\mathrm{D}=$ Durée totale - Durata total

$\mathrm{M}=$ Moment de la plus grande oseillation. - Momentul celei $a=$ Agrandissement. - Mărire, mai mari oscilaţiuni.

$$
\text { Bucureşti }\left\{\begin{array}{l}
\lambda=26^{\circ} .6^{x}, \mathrm{Gr} . \\
\uparrow=44^{\circ} .25, \mathrm{~N} .
\end{array}\right.
$$

Pendules horizontaux lourds de Bosch - $10 \mathrm{~kg}$ - Pendule orizontale grele Bosch.

B, dans le méridien, composante $\mathrm{E} \cdots \mathrm{W}$

$\mathrm{B}$, dans le premier vertical, composante $\mathrm{N}-\mathrm{S}$ Temps moyen de Greenwich, $0^{k}-24^{5}$.
$\mathrm{B}_{1}$ in planul meridian, componenta $\mathbf{E}-\mathbf{W}$

$\mathrm{B}_{2}$ in primul vertical, componenta

\begin{tabular}{|c|c|c|c|c|c|c|c|c|c|c|c|}
\hline $\begin{array}{c}\text { No. } \\
\quad \\
\end{array}$ & $\begin{array}{c}\text { DATE } \\
\text { D A T A }\end{array}$ & $\begin{array}{c}\text { Pend. } \\
3\end{array}$ & Comp. & 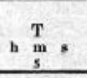 & h $\begin{array}{l}\mathrm{C} \\
\mathrm{m}\end{array}$ & $\mathbf{h} \underset{\mathbf{m}}{\mathbf{R}} \mathbf{s}$ & h $\underset{8}{\mathrm{M}}=$ & $\underset{\substack{\mathrm{mm} \\
9}}{\mathbf{A}}$ & $\begin{array}{l}a \\
10 \\
\end{array}$ & $\begin{array}{l}\mathrm{F} \\
\mathrm{m} \\
\mathrm{n}\end{array}$ & $\begin{array}{l}\mathrm{D} \\
\mathrm{A} \\
\end{array}$ \\
\hline 1 & III. 6 & $\begin{array}{l}\mathrm{B}_{1} \\
\mathrm{~B}_{2}\end{array}$ & $\underset{\mathrm{N}-\mathrm{S}}{\mathrm{E}-\mathrm{W}}$ & $\begin{array}{l}17.36 .33 \\
17.37 .4\end{array}$ & 17.37 .15 & $\stackrel{17.37 .15}{-}$ & $\begin{array}{l}17.37 .15 \\
17.37 .4\end{array}$ & $\begin{array}{l}2.4 \\
0.9\end{array}$ & $\begin{array}{l}1 / 10 \\
1 / 15\end{array}$ & 17.18 .30 & $\begin{array}{r}12^{\text {m }} \\
1)\end{array}$ \\
\hline 2 & III. 25 & $\begin{array}{l}\mathrm{B}_{1} \\
\mathrm{~B}_{2}\end{array}$ & $\underset{\mathbf{N}-\mathbf{S}}{\mathbf{E}-\mathbf{W}}$ & $22.33 \cdot 46$ & $\begin{array}{c}22.34 .6 \\
-\end{array}$ & $\overline{-}$ & $22.35 \cdot 20$ & 1.0 & $\begin{array}{l}1 / 10 \\
1 / 18\end{array}$ & $22.39,10$ & $s_{3}^{*}$ \\
\hline 3 & V. 26 & $\begin{array}{l}\mathbf{B}_{i} \\
\mathbf{B}_{2}\end{array}$ & $\underset{\mathrm{N}-\mathrm{S}}{\mathbf{E}-\mathbf{W}}$ & $\begin{array}{l}6.11 .25 \\
6.8 .25\end{array}$ & $\frac{6.12 .19}{-}$ & - & $\underbrace{6.12 .4 \mathrm{r}}$ & $\begin{array}{l}1.5 \\
0.5\end{array}$ & $1 / 2,15$ & $\underset{6.21 .3}{-}$ & $\begin{array}{l}10= \\
y\end{array}$ \\
\hline 4 & V. 29 & $\begin{array}{l}\mathrm{B}_{1} \\
\mathrm{~B}_{2}\end{array}$ & $\underset{\mathrm{N}-\mathrm{S}}{\mathrm{E}-\mathrm{W}}$ & $9.35 .5^{8}$ & $\begin{array}{l}9.37 .2 \\
9.37 .3 \mathrm{i}\end{array}$ & $\begin{array}{l}9.37 .12 \\
9.38 .6\end{array}$ & $\begin{array}{l}9.38 .8 \\
9.38 .16\end{array}$ & $\begin{array}{r}10.0 \\
5.0\end{array}$ & $\begin{array}{l}1 / 10 \\
1 / 18\end{array}$ & $\begin{array}{l}9.53 .5^{6} \\
9.39 .44\end{array}$ & $\begin{array}{r}18^{\circ} \\
2^{m}\end{array}$ \\
\hline 5 & VI. 8 & $\begin{array}{l}\mathbf{B}_{1} \\
\mathbf{B}_{2}\end{array}$ & $\begin{array}{c}\mathbf{E}-\mathbf{W} \\
\mathrm{N}-\mathrm{S}\end{array}$ & $\begin{array}{l}15.7 .12 \\
15.7 .12\end{array}$ & $15.7 .3^{2}$ & ${ }^{15.7 .32}$ & ${ }^{15.7 .3^{8}}$ & $\begin{array}{l}2.0 \\
0.9\end{array}$ & $\begin{array}{l}1 / 10 \\
1 / 15\end{array}$ & 15.12 .40 & $5^{n}$ \\
\hline 6 & VIII. it & $\begin{array}{l}\mathbf{B}_{1} \\
\mathbf{B}_{2}\end{array}$ & $\underset{N-S}{E-W}$ & $\begin{array}{l}4.34-31 \\
4.31 .15\end{array}$ & $\begin{array}{r}4 \cdot 35 \cdot 5^{5} \\
4 \cdot 35 \cdot 55\end{array}$ & $\begin{array}{r}4.36 .21 \\
4.56 .29 \\
\end{array}$ & $\begin{array}{l}4.36 .46 \\
4.37 .13\end{array}$ & $\begin{array}{l}26.0 \\
12.0\end{array}$ & $\begin{array}{l}1 / 10 \\
1 / 18\end{array}$ & $\begin{array}{l}4.48 .3 \\
4.43 .21\end{array}$ & $\begin{array}{r}14^{\prime \prime} \\
9^{\prime \prime}\end{array}$ \\
\hline 7 & IX. 13 & $\begin{array}{l}\mathrm{B}_{1} \\
\mathrm{~B}_{2}\end{array}$ & $\underset{N-S}{E-W}$ & $\begin{array}{l}8.2 .41 \\
8.3 .7\end{array}$ & $\begin{array}{l}8.3 .2 \\
8.3 .7\end{array}$ & $\begin{array}{l}8.3 .2 \\
8.3 .7\end{array}$ & $\begin{array}{l}8.3 .2 \\
8.3 .7\end{array}$ & $\begin{array}{l}73.0 \\
13.5\end{array}$ & $\begin{array}{l}1 / 10 \\
1 / 10\end{array}$ & $\begin{array}{l}8.7 .37 \\
8.5 .25\end{array}$ & 5" \\
\hline 8 & XI. 27 & $\begin{array}{l}\mathbf{B}_{1} \\
\mathbf{B}_{2}\end{array}$ & $\underset{N-S}{E-W}$ & 15.13 .13 & 15.13 .19 & 15.13 .19 & $\left.15.13 .27^{\circ}\right)$ & 2.5 & $\begin{array}{l}1 / 10 \\
1 / 15\end{array}$ & 15.14 .45 & $\left.2^{\prime \prime \prime}\right)$ \\
\hline 8 & XI. 30 & $\begin{array}{l}\mathrm{B}_{1} \\
\mathrm{~B}_{2}\end{array}$ & $\underset{N-S}{E-W}$ & 2.36 .6 & ${ }^{2.36 .20}$ & $\begin{array}{c}2.36 .20 \\
-\end{array}$ & ${ }^{2.3^{6}} \cdot 3^{8}$ & 3.0 & $\begin{array}{l}1 / 10 \\
1 / 15\end{array}$ & $\frac{2.38 .14}{-}$ & 2" \\
\hline 10 & XII. 5 & $\begin{array}{l}\mathrm{B}_{1} \\
\mathrm{~B}_{2}\end{array}$ & $\begin{array}{l}\mathbf{E}-\mathrm{W} \\
\mathrm{N}-\mathrm{S}\end{array}$ & ${ }^{20.47 .10}$ & 10.47 .10 & 10.47 .16 & 10.47 .20 & 1.0 & $\begin{array}{l}1 / 10 \\
1 / 13\end{array}$ & ${ }^{10.48 .12}$ & 1") \\
\hline
\end{tabular}

1) Il n'y a en qu'un seul déplacement vers le $\mathrm{S}$. - N'a fost de cat o singură mişcare spre $\mathrm{S}$.

3) Idem vers le $\mathrm{N}$. - Idem spre $\mathrm{N}$.

II n'a rien enregistré. - N'a inregistrat nimic.

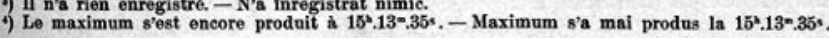

\section{B. Travaux des deux premières Conférences internationales de Sismologie}

Dans un précédent travail ${ }^{1}$ ) j'ai déjà dit quelques mots sur la manière dont on est arrivé à réunir à Strasbourg, en Avril 1901, la première Conférence sismologique internationale; si je reviens ici sur cette question c'est qu'elle présente un progrès dansl'étude des tremblements de terre.

L'un des plus grand et des plus intéressants problèmes de la Géophysique est certainement celni des tremblements de terre. Les perfectionnements apportés les derniers temps aux appareils sismographiques et l'étude isolée des sismes

\section{E. Lucrările primelor două Conferințe internaţionale de Sismologie}

Intr'o precedentă lucrare ${ }^{1}$ ) am spus câteva vorbe asupra modului cum s'a ajuns de a întrunî la Strassburg, în Aprilie 1901, prima conferinţă sismologică internaţională; dacă vin din nou asupra acestei chestiune cauza este că ea prezintănn progres însemnat în stadiul cutremurilor de pământ.

Una din cele mai mari şi mai interesante probleme ale Geofisicei este negreșii acela al cutremurelor de pământ. Perfecționările. făcute, in ultimii timpi. aparatelor sismografice şi studiul izolat al seismelor in unele parrţi ale lumii, au

1) Arhiva sismicŭ a Romaniei, An. 1901 in vol. XVII-lea din Analele Institutului Meteorologic al Romaniei.

Coaln $B$.

Fig. 7. Example of historical publication with reference to earthquakes in that period (from Romania Seismic Archive between 1902 and 1906). 


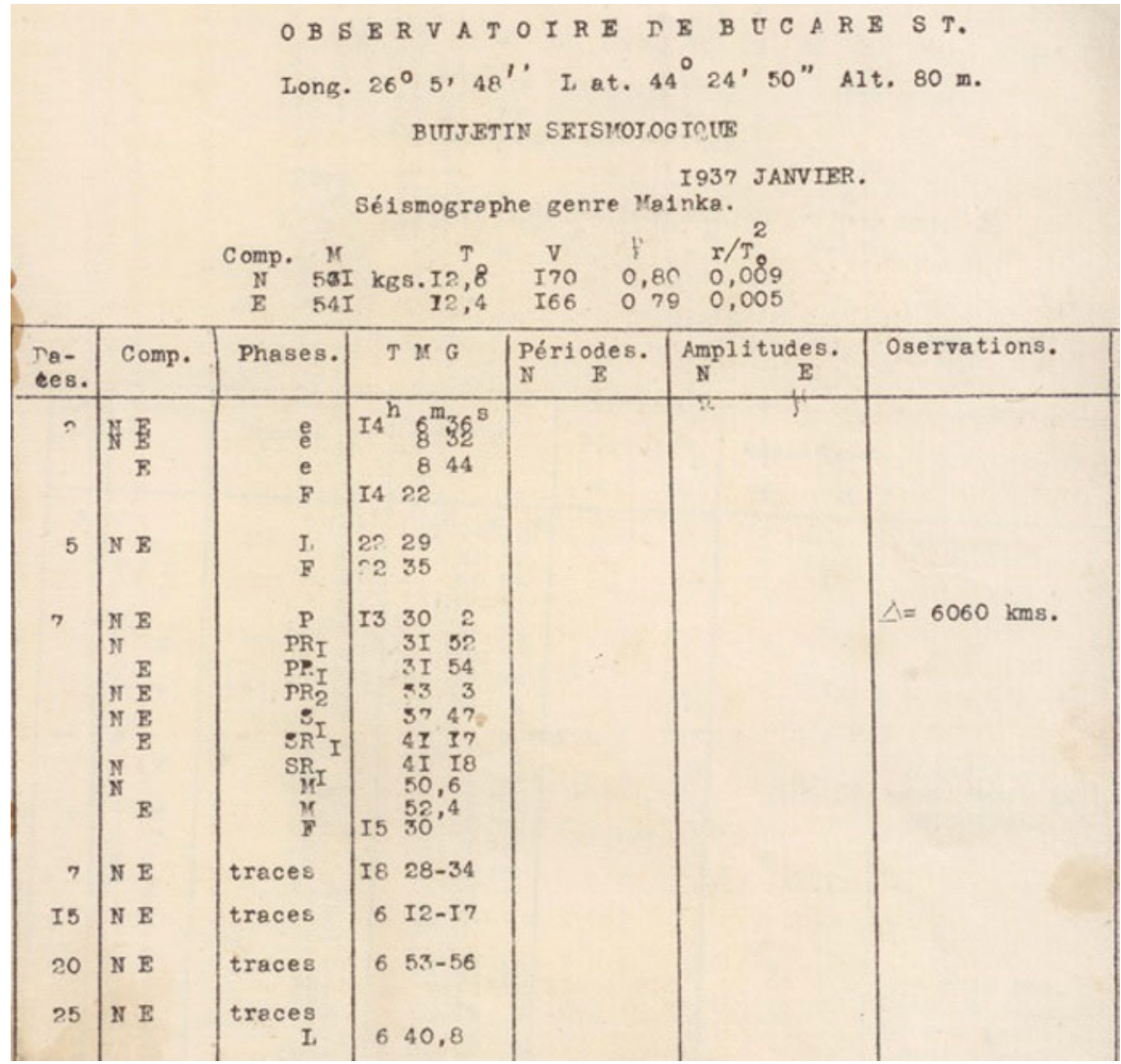

Fig. 8. Example of seismic bulletin with information about seismic station equipment and the recording phases of earthquakes.

tation (seismic bulletins, stations books, publications, etc.). In a first stage we shall complete the database by scanning all the available old seismograms recorded by the Romanian stations (hundreds of thousands). Then the database will be filled with digitized seismograms associated with identified earthquakes.

A managing system to collect data for historic events, archive (database construction) and analysis procedures was developed. The proposed system follows the same structure as the system developed in the framework of the Euroseismos Project (Saving and Studying the Seismograms of the Strongest Euro-Mediterranean Earthquakes, http://storing.ingv.it/es_web). This project allowed so far the recovery of more than 30000 historical seismograms from 29 countries that joined the project, including Romania. Our database is linked with the EuroSeismos Database. 
The organizing of the final database allows an easy access to the main seismic data, like seismograms, bulletins, macroseismic observations, papers, etc.

Digital format of the seismograms for significant Romanian earthquakes provides unique data for their advanced study, especially relocation of hypocenters and magnitude determination using more accuracy data, as well as the spectral parameters estimation (seismic moment, moment magnitude, corner frequency, fault dimensions, stress drop, etc.), synthetic seismograms and focal mechanism solutions.

On request, seismograms and metadata could be obtained and used for reanalyzing major events recorded at national, regional and global scale.

Acknowledgments. D. Paulescu had benefited of a research NERIES/SISMOS Grant (2008) within the project "Scanning, digitization and vectorization of historical seismograms recorded by Romanian seismic network for some strong Vrancea earthquakes". The first author benefited of a stage of specialization about scanning, digitization and vectorization of historical seismograms at INGV Roma (SISMOS Centre) within the European Commission (EC FP7) NERIES (Network of Research Infrastructures for European Seismology) Project (TA3-006, 12-22/06/2008). The authors are grateful to the editor and the reviewers for their valuable comments and suggestions.

\section{References}

Curea, I. (1961), Recent earthquakes in Banat, St. Cerc. Astr. Seism. 6, 2, 15-35 (in Romanian).

Demetrescu, G. (1956), Seismological office of the Observatory of Bucharest, St. Cerc. Astr. Seism. 1, 85-88 (in Romanian).

Dewey, J., and P. Byerly (1969), The early history of seismometry (to1900), Bull. Seismol. Soc. Am. 59, 1, 183-227.

Glover, D.P., and H. Meyers (1988), Historical seismogram filming project: current status. In: W.H.K. Lee, H. Meyers, and K. Shimazaki (eds.), Historical Seismograms and Earthquakes of the World, Academic Press, San Diego, 373-379.

Hepites, S.C. (1893), Cutremurele de pamant din Romania in anul 1902 st. n. (1) si in deceniul 1893-1902 (nota a opta), Anal. Acad. Romane 35, 544 (in Romanian). 
IRIS (2004), Preservation of WWSSN and historical seismograms, IDEAsRev.doc, Incorporated Research Institutions for Seismology, Washington, USA, available from: http://www.iris.edu/seismo/info/icpwhs/ideas.pdf.

Jeffreys, H. (1935), Some deep-focus earthquakes, Geophys. J. 3, 8, 310-343, DOI: 10.1111/j.1365-246X.1935.tb01741.x.

Kanamori, H. (1988), Importance of historical seismograms for geophysical research. In: W.H.K. Lee, H. Meyers, and K. Shimazaki (eds.), Historical Seismograms and Earthquakes of the World, Academic Press, San Diego, 16-33.

Kronrod, T., M. Radulian, G. Panza, M. Popa, I. Paskaleva, S. Radovanovich, K. Gribovszki, I. Sandu, and L. Pekevski (2013), Integrated transnational macroseismic data set for the strongest earthquakes of Vrancea (Romania), Tectonophysics 590, 1-23, DOI: 10.1016/j.tecto.2013.01.019.

Michelini, A., B. De Simoni, A. Amato, and E. Boschi (2005), Collecting, digitizing, and distributing historical seismological data, Eos Trans. $A G U \mathbf{8 6}, 28,261-$ 266, DOI: 10.1029/2005EO280002.

Pintore, S., M. Quintiliani, and D. Franceschi (2005), Teseo: A vectoriser of historical seismograms, Comput. Geosci. 31, 10, 1277-1285, DOI: 10.1016/ j.cageo.2005.04.001.

Radulescu, F. (2009), Romanian seismology - historical, scientific and human landmarks, Rev. Roum. Geophys. 52-53, 101-121.

Stucchi, M., A. Rovida, A.A. Gomez Capera, P. Alexandre, T. Camelbeeck, M.B. Demircioglu, P. Gasperini, V. Kouskouna, R.M.W. Musson, M. Radulian, K. Sesetyan, S. Vilanova, D. Baumont, D. Faeh, W. Lenhardt, K. Makropoulos, J.M. Martinez Solares, O. Scotti, M. Zivcic, P. Albini, J. Batllo, C. Papaioannou, R. Tatevossian, M. Locati, C. Meletti, D. Viganò, and D. Giardini (2013), The SHARE European Earthquake Catalogue (SHEEC) 1000-1899, J. Seismol. 17, 2, 523-544, DOI: 10.1007/ s10950-012-9335-2.

Received 23 February 2015

Received in revised form 3 August 2015

Accepted 6 August 2015 